\title{
Eco-Dyeing of Cashmere with Bio Preperations of Rheum Undalitum L. and Urtica Cannabina L.
}

\author{
Tserendulam. $S^{1}$, Nadmid.G ${ }^{1}$, Batchimeg.G ${ }^{1}$, Soyol-Undrakh. Kh, Batsuren.Ch ${ }^{1}$ \\ Research and Development Institute of Light Industry, \\ Mongolian University of Science and Technology, Mongolia
}

\begin{abstract}
This research was concerned with natural biopreperation extraction from plant an abundantly occurring plant namely Rhubarb (Rheum. Undulatum .L, nettle(Urtica.Cannabina.L), available almost everywhere in Mongolia and with the application of this dyeing bio-preperation for Mongolian goat cashmere dyeing by exhaustion process. Optimal results were achieved when dyeing with a rhubarb at 80 ${ }^{0} \mathrm{C}$ for 40-45 minutes and at $\mathrm{pH} 4.5$ and for dyeing with a nettle at $80{ }^{\circ} \mathrm{C}$ for $40-50$ minutes and at $\mathrm{pH}$ 5.0. Bio-preperation extract were applied on cashmere fabric with alum, copper, ferrous, magnesium sulfates mordants with four different dyeing conditions. An exception was when the fabrics were dyed with $\mathrm{FeSO}_{4}$ mordant, resulting in a shade of dark brown for two plants. The colour fastness to washing and rubbing after dyeing the cashmere fabrics treated with the mordant was investigated, the results of which showed fair to good rubbing fastness, specially the colour fastness to washing was at a good to very good level. The metal salts are used by mordants in the natural dyeing proceesing are increased 1-2 grade of colour fastness rating of dyed cashmere fabrics. The results confirmed that natural dyes from rhubarb and nettle have potential applications for fabric dyeing and producing ultraviolet (UV) protective cashmere fabrics.
\end{abstract}

Keywords: Natural Dye, Rhubarb, Nettle, UV Protection, Cashmere, Dyeing. Colorfastness

\section{INTRODUCTION}

Mongolians have ancient practices utilizing various medicinal plant species for their everyday life and for of traditional drugs[1, 2]. Medicinal plants contain biologically active components because a lots of plants possess therapeutic properties. At present, more than 3000 plant species using for Eastern Asian traditional medicine is under the focus of modern medical practices.

Another important attribute of such products of plant origin is their contribution as source of natural dye. The amounts of natural dye's coloring compounds vary in plants of the same spices depending upon the variety, soil and climate in which they have been grown.

The plants contain colouring compounds occur as complex organic substances such as glucosides, flavonoids, anthraquinones, etc.[3, 4]. The natural colourants derived from these sources are preferred due to their health effectiveness and good therapeutic properties[5].

Recently there has been a revival of interest in the use of natural dyes in textile coloration. This is a result of the stringent environmental standards imposed by many countries in response to the toxic and allergic reactions associated with the use of synthetic dyes.
A widespread interest has emerged in the dyeing of textile fibres using natural colorants, on account of their high compatibility with environment, unique and elegant colours, naturalness, low toxicity and antimicrobial, anti-allergic, deodorizing, anti-cancer, UV protection properties, harmonizing natural shades or novelty[6-12]. It's well known those problems in dyeing with natural dyes are low exhaustion of natural colorants and poor colorfastness of dyed fabrics. Attempts to overcome these problems have been focused on the use of some metallic salts as mordants, which are traditionally used to improve fastness properties or exhaustion and to develop different shades of the same dye[13-17].

Cashmere is rare luxury fiber with unique combination of properties including high water absorption, fire resistance, softness, resilience, high elacticity, comportable to wear, good dye-ability and colourfastness. Cashmere are very important fiber for human well being to live in the eco-friendly textile products. Due to these special properties of Mongolian cashmere facts, eco-friendly processing (natural dyeing, finishing) is critical to the added value of the resulting materials.Therefore it should be study of cashmere natural dyeing by natural dyes for development to create 'Mongolian pure eco product'.

Natural dyes can give suitable and elegant colours through to the brightest colour to the fibers, yarns and fabrics. The major parts of natural dyes are anthraquinone, anthocyanin and flavonoid dyes, or polyphelolic compounds most of which have yellow, red and brown shades(Bechtold and Mussak., 2009)[4].

Rheum Undalitum.L commonly known as rhubarb, is a herb of 0.3-0.8 $\mathrm{m}$ in height, distributed in the Altai, Khangai and Dornod area. The roots are the chief source of Mongolian rhubarb and finds application in medicine as a purgative and astringent tonic and plant leaves, stems can also be used for colouration of textile materials.[18-24].

The rhubarb's major active constituents are a number of anthraquinone derivatives based on rhein, emodin, aloeemodin and chrysophanol and tannins, flavanoids etc....

Anthraquinone dyes belong to the group of most durable dye, so they are often used in products that must satisfy strict requirements. Anthraquinones are relatively stable and good lightfastness, had they give bright colors(Bechtold and Mussak ., 2009[4]). 
The chief colouring component of Rheum Undalitum. L are chrysophanic acid, rhein and emodin, the structure of which are given in Fig 1.
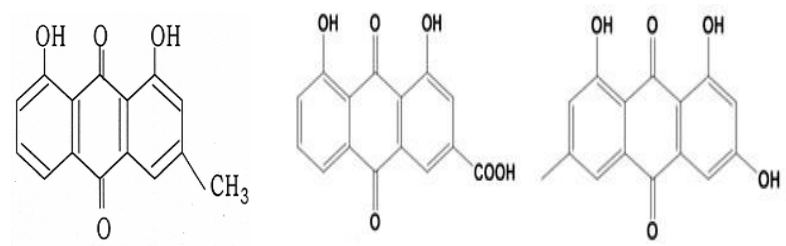

Fig. 1. Chrysophanic acid, Rhein, Emodin

Urtica.Cannabina.L is commonly known as nettle, is high herb of $1.5-3.0 \mathrm{~m}$ in height, distributed in the almost everywhere in Mongolia[1, 2]. The herbs are the chief source of Mongolian nettle and finds application in medicine and food as source vitamin $\mathrm{C}$ by the small height in spring, and to produce as raw material shampoo and conditioner and can also be used for colouration of textile materials.

The major active constituents of Urtica.Cannabina.L are protein chlorolphylls a, b, c and quercetin, luteolin,tannic and gallic acids, free amino acids, vitamins A, C, D, E, F, K, P and $\mathrm{b}$-complexes as well as thiamin, riboflavin, niacin also high content of the metals selenium, zinc, iron and magnesium.

Most of the natural yellows are derivatives of hydroxyl and methoxy substituted flavones and isoflavones. Flavonoids are giving brilliant colours on wool and silk and the structure of which are given in Figure 2.
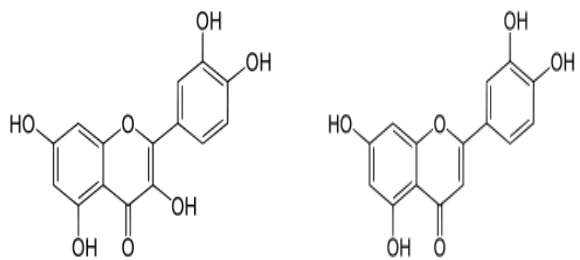

Fig 2. Quercetin, Luteolin

And In the present study, the plant bio-preperation from these plants, the consumption that for dyeing on Mongolian cashmere and identified their efficacy as natural colorant evaluated by using some metal mordants for dyeing.

\section{MATERILAS AND METHODS}

\section{Materials}

Natural lightgrey goat cashmere fabric (thickness 0.74 $\mathrm{mm}$, weight $295 \mathrm{~g} / \mathrm{m} 2$ ) by the commercially produced by Gobi Ltd, was scoured with an aqueous nonionic surfactant solution at a temperature of $45{ }^{\circ} \mathrm{C}$ for 20 minutes, then it was thoroughly rinsed with cold water and air dried at room temperature.

\section{Mordants and chemicals}

The following laboratory-grade chemicals and mordants were used:
- acetic $\operatorname{acid}\left(\mathrm{CH}_{3} \mathrm{COON}\right)$ for $\mathrm{pH}$ correction

- non-ionic detergent(CTA) for washing fastness

- aluminium sulfate dodecahydrate $\left(\mathrm{Al}_{2}\left(\mathrm{SO}_{4}\right)_{3}\right.$. $\left.12 \mathrm{H}_{2} \mathrm{O}\right)$

- ferrous(II) sulfate heptahydrate $\left(\mathrm{FeSO}_{4} \cdot 7 \mathrm{H}_{2} \mathrm{O}\right)$,

- copper(II) sulfate pentahydrate $\left(\mathrm{CuSO}_{4} .5 \mathrm{H}_{2} \mathrm{O}\right)$,

- magnesium (II) sulfate heptahydrate $\left(\mathrm{MgSO}_{4}\right.$ $7 \mathrm{H}_{2} \mathrm{O}$ )

Plants

Fresh nature Rheum Undalitum. $L$ and Urtica.Cannabina.L leaves, stems were collected, dried in air $20-25^{\circ} \mathrm{C}$ in the dark room.

After completed to dry they were made into a fine powder by crushing and grinding.

This powders were used in all succeeding experiments to extract bio-preperation of plants to dyeing. Plants are given Figure 3.
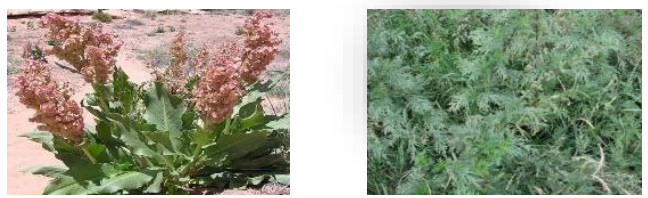

Fig.3. Rheum undalitum L., Urtica cannabina L. Urticannabina.L

Optimization of extraction conditions

Dye solutions by water were prepared to optimize extracting parameters such as time, temperature and M:L ratio.

Optimization conditions:

Time: 30, 40, 60, 80 and 100 minute

Temperature: $70,80,90^{\circ} \mathrm{C}$,

Plant powder : Water ratio: 1:10, 1:20 and 1:30.

The samples were heated with stirring at extraction conditions and $f$ filtered. Concentration of the bio-preperation solutions was analyzed by spectrophotometer for maximium absorption and optical density and used for obtaining a standard calibration curve.

The dilution of bio-preperation gives a relatively clear solution with linear dependance on the concentration absorbance relation at an absorption peak $(\lambda \max )$ [25].

\section{Dyeing and Mordanting}

Four different dyeing conditions were varied (without mordant, pre-mordanting, meta-mordanting, postmordanting) to study the effect on the amount of plant biopreperation uptake, color fastness, UV protection factor(UPF) on goat cashmere.

\section{Evaluation of color performance and fastness properties}

The color performance and colour strength $(\mathrm{K} / \mathrm{S})$ were analysed the CIE $\mathrm{L} *, \mathrm{a} *, \mathrm{~b} *$ colour scale of the dyed samples were evaluated by Datacolor 2000. 
Positive for $\mathrm{L} *$ represents a lightness, negative $\mathrm{L}$ is darker. Positive for $\mathrm{a}^{*}$ values indicate amounts of red, negative $\mathrm{a}^{*}$ values indicate amounts of green. Positive for $b^{*}$ corresponds to yellowness and negative $b^{*}$ corresponds to blueness. The average color values for the dyed samples as following these equations $1,2,3$ :

$$
\begin{gathered}
\text { Chroma }(D C *)=\sqrt{\mathrm{a}^{2}+\mathrm{b}^{2}} \\
\text { Color difference }(D E *)=\left[\Delta \mathrm{L} *^{2}+\Delta \mathrm{a} *^{2}+\Delta \mathrm{b} *^{2}\right]
\end{gathered}
$$

All the samples measured showed a maximum absorption wavelength $(\lambda \max )$ value at $400 \mathrm{~nm}$. The $\mathrm{K} / \mathrm{S}$ is a function of colour depth and is calculated by the Kubelka Munk equation 4:

$$
\text { color strength }(\mathrm{K} / \mathrm{S})=\frac{(1-R)^{2}}{2 R}
$$

where $\mathrm{R}$ is the reflectance, $\mathrm{K}$ - the sorption coefficient, and $\mathrm{S}$ is the scattering coefficient.

The colour fastness to washing, light and rubbing of the dyed samples was determined according to ISO 105-C06 A1S:1994, ISO 105-B02:1994 and ISO 105-X12:2001, and evaluated the color fastness of dyed fabrics by the grade 1 to 5 , that 5, 4-5 grade is good fastness or 2, 2-3 grade is poor etc..

\section{Evaluation of $U V$ protection}

The transmittance and UPF values of the original cashmere fabrics, and fabrics dyed with plant bio-preperation extract were measured using a Shimadzu UV2550 PC (UV-VIS-NIR Scanning Spectrophotometer) in the range of $190 \mathrm{~nm}$ to 400 $\mathrm{nm}$.

The UPF value of each fabric was determined from the total spectral transmittance based on AATCC 183 as follows[26]

$$
U P F=\frac{E D}{E D m}=\frac{\sum_{290}^{400} E_{\lambda} \mathrm{S}_{\lambda} \Delta \lambda}{\sum_{290}^{400} E_{\lambda} S_{\lambda} \mathrm{T}_{\lambda} \Delta \lambda}
$$

where $E \lambda$ is the relative erythemal spectral effectiveness (unitless), $\mathrm{S} \lambda$ - the solar ultraviolet radiation (UVR) spectral irradiance in W. m-2.nm-1, T $\lambda$ - the measured spectral transmission of the fabric, $\Delta \lambda$ - the bandwidth in millimeters, and $\lambda$ is the wavelength in nanometres.

The UVR band consists of three regions: the UV-A band ( $320 \mathrm{~nm}$ to $400 \mathrm{~nm}$ ), the UV-B band $(290 \mathrm{~nm}$ to $320 \mathrm{~nm}$ ), and the UV-C band (200 $\mathrm{nm}$ to $290 \mathrm{~nm}$ ) [27].

The highest energy region, the UV-C band, is completely absorbed by oxygen and ozone in the upper atmosphere. Of the solar UV radiation reaching the earth's surface, $6 \%$ is in the UV-B region and $94 \%$ is in the UV-A region [29].

UV-A causes little visible reaction on the skin but has been shown to decrease the immunological response of skin cells [28].

$\mathrm{UV}-\mathrm{B}$ is the most responsible for the development of skin cancers [28].
Therefore, the transmittance of UVR (UV-A and UV-B) through the fabrics was evaluated in this experiment.

Fabrics with a UPF value in the range of 15 to 24 are defined as providing "good UV protection", 25 to 39 as "very good UV protection", and 40 or greater as "excellent UV protection" [28]. There is no rating assigned if the UPF value is greater than 50 .

\section{RESULTS AND DISCUSSION}

\section{$U V$-visible spectrum}

The UV spectrum of the plant aqueous bio-preperations is indicated good absorb radiation in the UV-C region(200-290 $\mathrm{nm})$, the UV-B region(290-320nm) and the UV-A region(320-400 $\mathrm{nm})$.

Absorption of these bio-preperations in the UV-B region can be expected to offer good protection from harmful UV radiation.

\section{Colorimetric properties}

In this study, the dyeing time and temperature were at 40 $50 \mathrm{~min}$ and $80^{\circ} \mathrm{C}$, respectively. It was the optimum dyeing conditions of our experiment's plant bio-preperation[30].

The color properties $\left(\mathbf{L}^{*}, \mathbf{a}^{*}, \mathbf{b}^{*}, \mathbf{D E} *, \mathbf{D C}^{*}\right)$ and dye strengths $(\mathbf{K} / \mathbf{S})$ of dyed with mordanting fabrics were determined by comparing the values of dyed without mordanting cashmere fabrics(Table 2,3).

Color properties of goat cashmere fabrics dyed with Rheum Undalitum L.

Table. 2

\begin{tabular}{|l|l|l|l|l|l|l|l|}
\hline \multirow{3}{*}{ Methods } & \multirow{2}{*}{$\mathrm{Me}$} & \multicolumn{6}{l}{ Colour performance } \\
\cline { 2 - 9 } without & - & $8.2 \mathrm{D}$ & $1.3 \mathrm{G}$ & 6.5 & 10.5 & 6. & 16.4 \\
\hline \multirow{4}{*}{$\begin{array}{l}\text { Pre- } \\
\text { mordanting }\end{array}$} & $\mathrm{Al}$ & 0.2 & $1.4 \mathrm{G}$ & 0.9 & 1.7 & 0.9 & 17.5 \\
\cline { 2 - 9 } & $\mathrm{Cu}$ & $5.8 \mathrm{D}$ & $3.2 \mathrm{G}$ & $1.3 \mathrm{~B}$ & 6.8 & $1.4 \mathrm{~L}$ & 15.9 \\
\cline { 2 - 9 } & $\mathrm{Fe}$ & $12.2 \mathrm{D}$ & $0.1 \mathrm{G}$ & $3.6 \mathrm{~B}$ & 12.7 & $3.6 \mathrm{~L}$ & 24.3 \\
\cline { 2 - 9 } & $\mathrm{Mg}$ & $0.7 \mathrm{D}$ & $1.9 \mathrm{G}$ & 0.9 & 2.3 & 0.8 & 15.4 \\
\hline \multirow{4}{*}{$\begin{array}{l}\text { Meta- } \\
\text { mordanting }\end{array}$} & $\mathrm{Al}$ & 5.4 & 0.2 & $1.3 \mathrm{~B}$ & 5.6 & $1.3 \mathrm{~L}$ & 9.2 \\
\cline { 2 - 9 } & $\mathrm{Cu}$ & $7.3 \mathrm{D}$ & $5.1 \mathrm{G}$ & $0.9 \mathrm{~B}$ & 9.0 & $0.8 \mathrm{~L}$ & 15.5 \\
\cline { 2 - 9 } & $\mathrm{Fe}$ & $11.5 \mathrm{D}$ & $0.3 \mathrm{G}$ & $5.6 \mathrm{~B}$ & 12.8 & $5.6 \mathrm{~L}$ & 16.7 \\
\cline { 2 - 9 } & $\mathrm{Mg}$ & 3.1 & 0.03 & $2.8 \mathrm{~B}$ & 4.2 & $2.7 \mathrm{~L}$ & 13.3 \\
\hline \multirow{4}{*}{$\begin{array}{l}\text { Post- } \\
\text { mordanting }\end{array}$} & $\mathrm{Al}$ & 3.9 & $1.0 \mathrm{G}$ & $1.2 \mathrm{~B}$ & 4.2 & $1.3 \mathrm{~L}$ & 8.7 \\
\cline { 2 - 9 } & $\mathrm{Cu}$ & $7.9 \mathrm{D}$ & $6.5 \mathrm{G}$ & $3.1 \mathrm{~B}$ & 10.7 & $2.8 \mathrm{~L}$ & 17.0 \\
\cline { 2 - 8 } & $\mathrm{Fe}$ & $15.3 \mathrm{D}$ & $0.2 \mathrm{G}$ & $4.4 \mathrm{~B}$ & 15.9 & $4.4 \mathrm{~L}$ & 21.5 \\
\cline { 2 - 8 } & $\mathrm{Mg}$ & 5.3 & $0.5 \mathrm{G}$ & $0.9 \mathrm{~B}$ & 5.4 & $1.0 \mathrm{~L}$ & 9.8 \\
\hline
\end{tabular}

Color properties of goat cashmere fabrics dyed with Urtica Cannabina L.

Table. 3

\begin{tabular}{|l|l|l|l|l|l|l|l|}
\hline \multirow{4}{*}{ Methods } & \multirow{2}{*}{$\mathrm{Me}$} & \multicolumn{2}{|l|}{ Colour performance } \\
\cline { 2 - 8 } & $\mathrm{L}^{*}$ & $\mathrm{a}^{*}$ & $\mathrm{~b}^{*}$ & $\mathrm{DE}^{*}$ & $\mathrm{DC}^{*}$ & $\mathrm{~K} / \mathrm{S}$ \\
\hline without & - & $20.6 \mathrm{D}$ & 4.0 & 19.4 & 28.6 & 19.8 & 4.4 \\
\hline \multirow{4}{*}{$\begin{array}{l}\text { Pre- } \\
\text { mordanting }\end{array}$} & $\mathrm{Al}$ & 4.0 & $0.5 \mathrm{G}$ & 10.2 & 10.9 & 9.9 & 4.7 \\
\cline { 2 - 9 } & $\mathrm{Cu}$ & $3.7 \mathrm{D}$ & $0.8 \mathrm{G}$ & 1.7 & 4.1 & 1.5 & 6.3 \\
\cline { 2 - 9 } & $\mathrm{Fe}$ & $16.3 \mathrm{D}$ & $4.7 \mathrm{G}$ & $10.7 \mathrm{~B}$ & 20 & $11.3 \mathrm{~L}$ & 8.3 \\
\cline { 2 - 9 } & $\mathrm{Mg}$ & 1.9 & 3.3 & 3.6 & 5.3 & 4.3 & 5.2 \\
\hline \multirow{4}{*}{$\begin{array}{l}\text { Meta- } \\
\text { mordanting }\end{array}$} & $\mathrm{Al}$ & 9.7 & $0.9 \mathrm{G}$ & 11.1 & 14.8 & 10.8 & 2.5 \\
\cline { 2 - 8 } & $\mathrm{Cu}$ & $5.3 \mathrm{D}$ & $1.4 \mathrm{G}$ & $2.9 \mathrm{~B}$ & 6.2 & $3.1 \mathrm{~L}$ & 7.7 \\
\cline { 2 - 8 } & $\mathrm{Fe}$ & $14.3 \mathrm{D}$ & $4.0 \mathrm{G}$ & $12.7 \mathrm{~B}$ & 19.5 & $13.2 \mathrm{~L}$ & 7.1 \\
\cline { 2 - 8 } & $\mathrm{Mg}$ & 2.7 & 2.7 & 3.3 & 5.0 & 3.8 & 2.9 \\
\hline \multirow{4}{*}{$\begin{array}{l}\text { Post- } \\
\text { mordanting }\end{array}$} & $\mathrm{Al}$ & 5.2 & $2.0 \mathrm{G}$ & 1.7 & 5.8 & 1.3 & 3.0 \\
\cline { 2 - 8 } & $\mathrm{Cu}$ & $9.2 \mathrm{D}$ & $1.1 \mathrm{G}$ & $5.9 \mathrm{~B}$ & 10.9 & $6 \mathrm{~L}$ & 6.5 \\
\cline { 2 - 8 } & $\mathrm{Fe}$ & $21.0 \mathrm{D}$ & $4.4 \mathrm{G}$ & $18 \mathrm{~B}$ & 28.0 & $18.5 \mathrm{~L}$ & 9.8 \\
\cline { 2 - 8 } & $\mathrm{Mg}$ & 2.0 & 1.0 & $2.9 \mathrm{~B}$ & 3.7 & $2.6 \mathrm{~L}$ & 2.7 \\
\hline
\end{tabular}


Table 2, 3, Figure 4, 5 show color performance $\left(\mathrm{L}^{*}, \mathrm{a}^{*}, \mathrm{~b}^{*}, \mathrm{DE}^{*}\right.$, $\mathrm{DC}^{*}, \mathrm{~K} / \mathrm{S}$ ) of cashmere fabrics dyed with Rheum Undalitum L and Urtica Cannabina L bio-preperation extract. The values quoted are the average of five measurements.

Generally, the dyeing affinity of textile materials is dependent on the content and type/polarity of functional groups of fiber. Cashmere and wool fiber"s finctional group is larger than other fibers and polarity of protein fibers is higher than others.

The experiments were dyed without and with metal salts using three different dyeing methods: pre-mordanting, metamordanting and post-mordanting. The mordant activity sequence were $\mathrm{FeSO} 4>\mathrm{CuSO} 4>\mathrm{Al}_{2}(\mathrm{SO} 4)_{3}>$ without mordanting $>\mathrm{MgSO} 4$ for the cashmere fabrics. In all cases, the ferrous sulfate mordant yielded the best dyeing results.

The cashmere fabric dyed with rhubarb bio-preperation showed a bright, duller color than nettle bio-preperation.

\section{Rheum Undalitum L.}

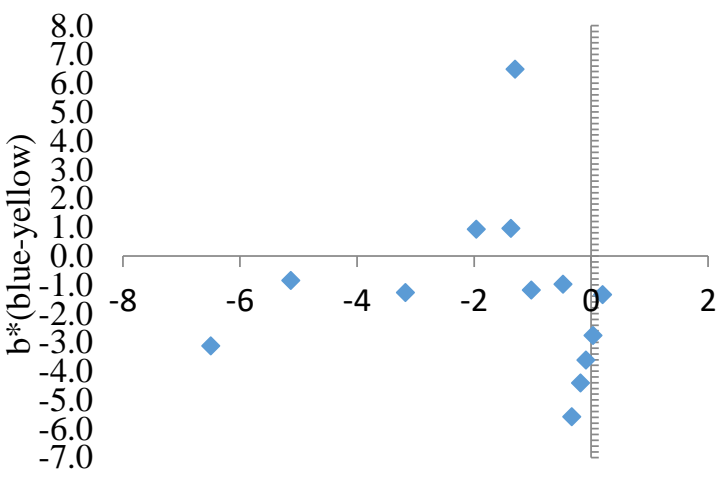

$\mathrm{a}^{*}($ green-red $)$

Fig 4.Various colors of dyed cashmere fabrics on coordinate $\mathrm{a} *$ (greenness-redness) and $\mathrm{b} *$ (blueness-yellowness).

\section{Urtica Cannabina L.}

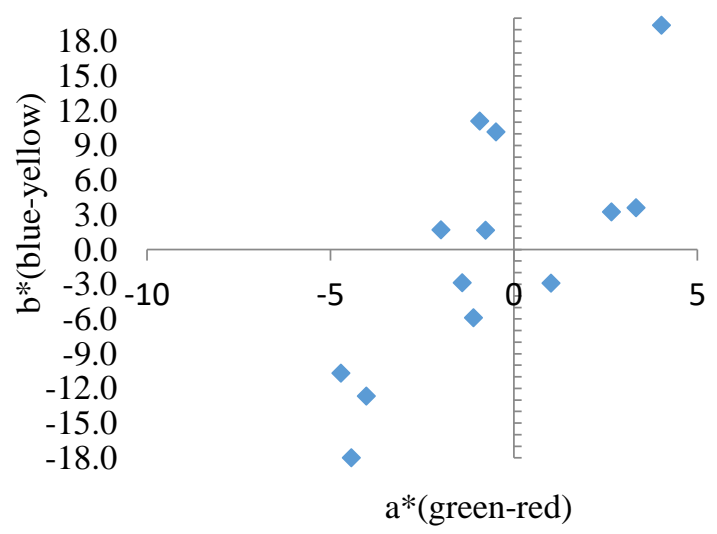

Fig 5. Various colors of dyed cashmere fabrics on coordinate $\mathrm{a} *$ (greenness-redness) and $\mathrm{b}^{*}$ (blueness-yellowness).

Various elegant different colors were obtained using Rhubarb(yellow-to darkbrown) and Nettle(light green to brown) with some metal mordants(Figure 6, 7).

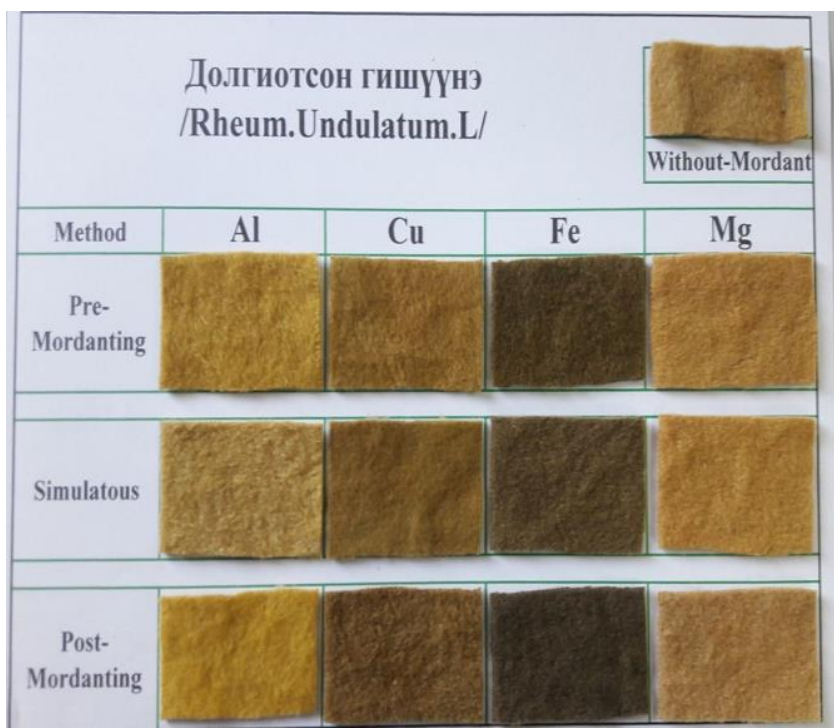

Fig 6.. Various colors of dyed cashmere fabrics with Rheum Undalitum L.

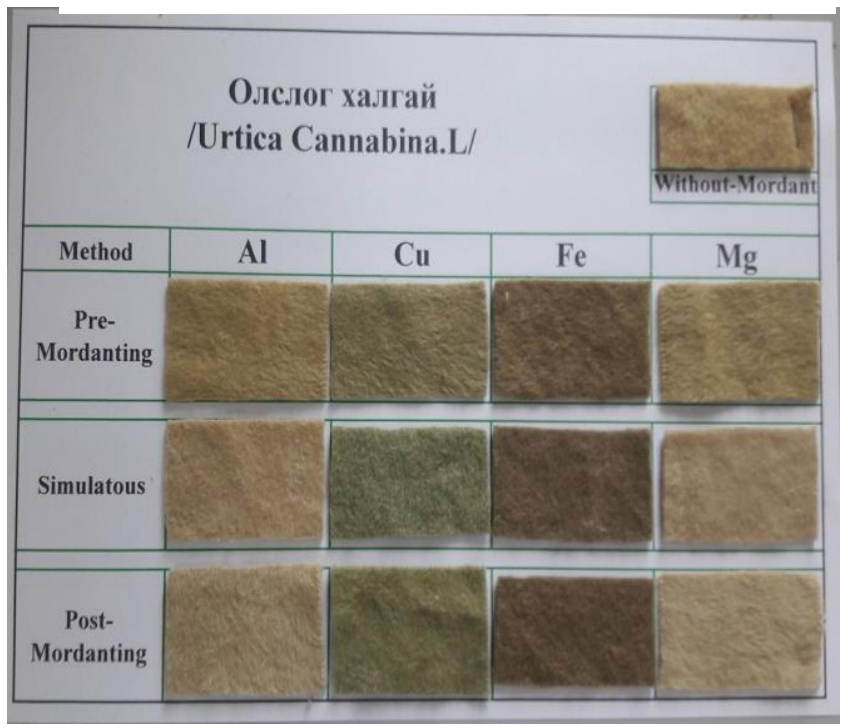

Fig 7. Various colors of dyed cashmere fabrics with Urtica Cannabina L.

Ferrous sulfate and copper sulfate mordants are well known for their ability to form coordination complexes and to readily chelate with the dye. As the coordination numbers of ferrous sulfate and copper sulfate are 6 and 4, respectively, some coordination sites remain unoccupied when they interact with the fibre.

Functional groups such as amino and carboxylic acid on the cashmere fibre can occupy these sites. Thus, the metal can form a ternary complex on which one site is with the fibre and the other site is with the dye [31]. Magnesium and alum ions form weak coordination complexes with dye; they tend to form quite strong bonds with the dye but not with the fibre, hence they block the dye and reduce dye interaction with the fibre [31]. 
The values results obtained(Table 2,3) show that cashmere fabrics dyed with magnesium and without a mordant a bright yellow and green color. The samples mordanted with alum and copper sulfate produced a medium to dark yellowish-brown and yellow, light green colours. With ferrous sulfate, the colour shade was darker and duller color. Additionally, tannins in the rhubarb bio-preperation combine with ferrous salts to form complexes, which also results in a darker shade of cashmere fabric [32].

\section{Colorfastness test}

The fastness to washing rating of cashmere fabrics dyed with or without mordants are presented in Tables 4, 5 .

Colour fastness to washing at $40^{\circ} \mathrm{C}$

(MNS ISO $105-\mathrm{C} 10: 2014$ )

Table 4.

\begin{tabular}{|l|l|l|l|l|l|}
\hline \multirow{2}{*}{ Fastness } & \multicolumn{5}{l|}{ Cashmere fabric } \\
\cline { 2 - 6 } & \multicolumn{4}{|l|}{ Rheum undalitum L. } \\
\cline { 2 - 6 } & without & $\mathrm{Al}$ & $\mathrm{Cu}$ & $\mathrm{Fe}$ & $\mathrm{Mg}$ \\
\hline Colour change & 4 & 4 & $4-5$ & $4-5$ & 4 \\
\hline Colour stanning & & & & & \\
\hline Acetate & $4-5$ & 5 & 5 & 5 & 5 \\
\hline Cotton & 4 & 5 & $4-5$ & 5 & 5 \\
\hline Nylon & $4-5$ & 5 & 5 & 5 & 5 \\
\hline Polyester & $4-5$ & 5 & 5 & 5 & 5 \\
\hline Acrylic & $4-5$ & 5 & 5 & 5 & 5 \\
\hline Wool & $4-5$ & 5 & 5 & 5 & 5 \\
\hline
\end{tabular}

Colour fastness to washing at $40^{\circ} \mathrm{C}$

(MNS ISO $105-\mathrm{C} 10: 2014$ )

Table 5.

\begin{tabular}{|l|l|l|l|l|l|}
\hline \multirow{3}{*}{ Fastness } & \multicolumn{5}{l|}{ Cashmere fabric } \\
\cline { 2 - 6 } & \multicolumn{4}{|l|}{ Urtica cannabina L. } \\
\cline { 2 - 6 } & without & $\mathrm{Al}$ & $\mathrm{Cu}$ & $\mathrm{Fe}$ & $\mathrm{Mg}$ \\
\hline Colour change & 4 & 4 & $4-5$ & $4-5$ & 4 \\
\hline Colour stanning & & & & & \\
\hline Acetate & $4-5$ & 5 & 5 & 5 & 5 \\
\hline Cotton & $4-5$ & 5 & $4-5$ & 5 & 5 \\
\hline Nylon & $4-5$ & 5 & 5 & 5 & 5 \\
\hline Polyester & $4-5$ & 5 & 5 & 5 & 5 \\
\hline Acrylic & $4-5$ & 5 & 5 & 5 & 5 \\
\hline Wool & $4-5$ & 5 & 5 & 5 & 5 \\
\hline
\end{tabular}

Table 4, 5 indicate that the washing fastness ratings of the cashmere fabrics dyed with rhubarb and nettle were good to very good (4 to $4-5)$.

Colour fastness to rubbing

(MNS ISO 105 - X12 : 2014)

Table 6.

\begin{tabular}{|l|l|l|}
\hline \multirow{3}{*}{ Mordant } & \multicolumn{2}{|l|}{ Colour stanning } \\
\cline { 2 - 3 } & \multicolumn{2}{|l|}{ Rheum undalitum L. } \\
\cline { 2 - 3 } & Dry rubbing & Wet rubbing \\
\hline without & 4 & $3-4$ \\
\hline $\mathrm{Al}$ & $4-5$ & $4-5$ \\
\hline $\mathrm{Cu}$ & 4 & 4 \\
\hline $\mathrm{Fe}$ & 4 & $3-4$ \\
\hline $\mathrm{Mg}$ & $4-5$ & 4 \\
\hline
\end{tabular}

Colour fastness to rubbing

(MNS ISO 105 - X12 : 2014)

Table 7.

\begin{tabular}{|l|l|l|}
\hline \multirow{3}{*}{ Mordant } & \multicolumn{2}{|l|}{ Colour stanning } \\
\cline { 2 - 3 } & Urtica cannabina L. \\
\cline { 2 - 3 } & Dry rubbing & Wet rubbing \\
\hline without & 4 & $3-4$ \\
\hline $\mathrm{Al}$ & $4-5$ & $4-5$ \\
\hline $\mathrm{Cu}$ & $4-5$ & 4 \\
\hline $\mathrm{Fe}$ & 4 & 4 \\
\hline $\mathrm{Mg}$ & $4-5$ & 4 \\
\hline
\end{tabular}

Table 6, 7 indicate that the to rubbing fastness ratings of the cashmere fabrics dyed with rhubarb and nettle were fair to good and very good(3-4 to 4-5).

However the colour fastness to rubbing is shown in the range of 4 to 4-5 (good to very good), except for the cashmere fabrics mordanted with ferrous sulfate, whose rating was only 3-4 to 4(fair to good) when subjected to wet rubbing.

The good fastness properties of cashmere fabrics dyed with rhubarb and nettle bio-preperations is attributed to the fact that these dyes contain tannin, flavonoids which may help in covalent bond formation with the fibre, thereby resulting in good fixation on the material.

Moreover, these tannins, flavonoids having a phenolic structure, can form metal chelation with different mordants.

The metal ions of mordants can act as electron acceptors for electron donors to form coordination bonds with the dye molecules, making them insoluble in water.

Hence, after mordanting, these tannins are insoluble in water, ultimately improving washing fastness [33].

\section{$U V$ protection property}

To investigate the UV-protection property of rhubarb and nettle bio-preperations, the UV transmittance spectra of cashmere fabrics with and without dyeing with mordants were compared Table 8, 9 .

UPF values and protection class of cashmere fabrics dyed rhubarb bio-preperation with metal mordants

Table 8.

\begin{tabular}{|l|l|l|}
\hline \multirow{2}{*}{ Condition } & \multicolumn{2}{|c|}{ Rheum undalitum L. } \\
\cline { 2 - 3 } & UPF & UV protection class \\
\hline Undyed & 10.75 & No class \\
\hline Dyed without mordant & 270 & Excellent \\
\hline $\mathrm{Al}$ & 155 & Excellent \\
\hline $\mathrm{Cu}$ & 271 & Excellent \\
\hline $\mathrm{Fe}$ & 2270 & Excellent \\
\hline $\mathrm{Mg}$ & 273 & Excellent \\
\hline
\end{tabular}


UPF values and protection class of cashmere fabrics dyed nettle bio-preperation with metal mordants

Table 9.

\begin{tabular}{|l|l|l|}
\hline \multirow{2}{*}{ Condition } & \multicolumn{2}{|l|}{ Urtica cannabina $\boldsymbol{L}}$. \\
\cline { 2 - 3 } & UPF & UV protection class \\
\hline Undyed & 10.75 & No class \\
\hline Dyed without mordant & 130 & Excellent \\
\hline $\mathrm{Al}$ & 73 & Excellent \\
\hline $\mathrm{Cu}$ & 101 & Excellent \\
\hline $\mathrm{Fe}$ & 274 & Excellent \\
\hline $\mathrm{Mg}$ & 60 & Excellent \\
\hline
\end{tabular}

Table 8, 9 show the UPF values and protection class of cashmere fabrics dyed with rhubarb and nettle bio-preperation with and without metal mordants.

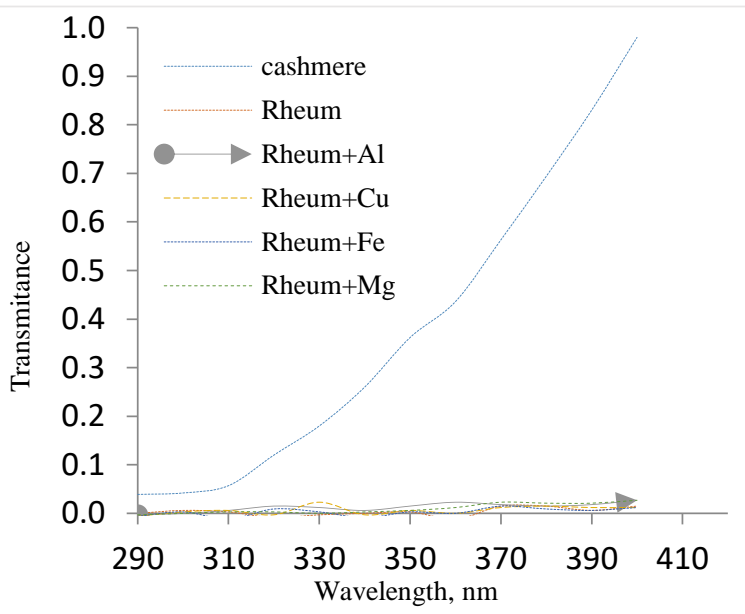

Fig 8. UV transmittance of cashmere fabric dyed with rhubarb bio-preperation with and without metal mordants

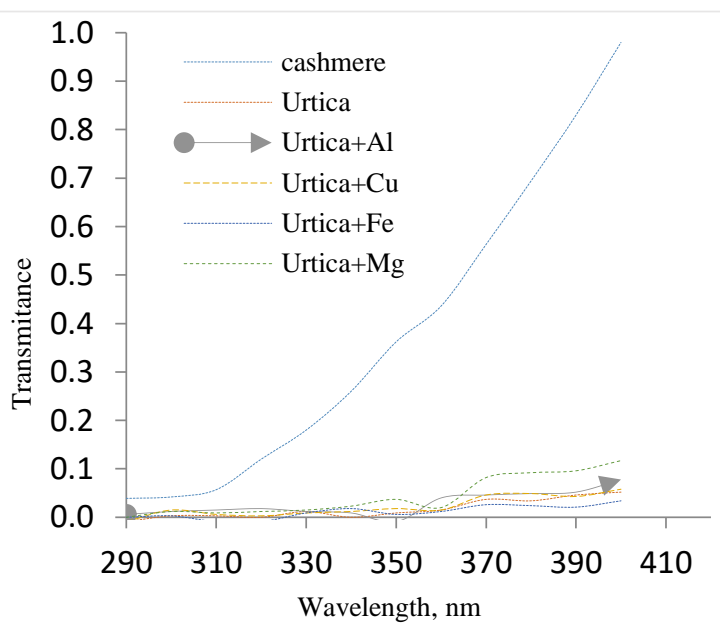

Fig 9. UV transmittance of cashmere fabric dyed with nettle bio-preperation with and without metal mordants
The cashmere fabrics dyed with and without metal mordants were rated as "excellent UV protection".

Cashmere fabrics are rated as "excellent UV protection" after dyeing with or without a mordant because cashmere fabric has low porosity and high weight and thickness (Figure 8, 9). Therefore, cashmere fabric gives a high UPF by allowing less UV penetration.

\section{CONCLUSIONS}

The best result for cashmere dyeing with rhubarb biopreperation was achieved when a temperature of $80{ }^{\circ} \mathrm{C}$ and pH 4.5 were employed for 40-45 minutes and dyeing with nettle bio-preperation was a temperature of $80^{\circ} \mathrm{C}$ and $\mathrm{pH} 5.0$ were employed for 40-50 minutes

The cashmere fabric dyed with rhubarb bio-preperation show higher K/S values than nettle.

The use of a ferrous sulfate mordant gives rise to the best dyeing, exhibiting a darker shade. The cashmere fabrics dyed with a rhubarb bio-preperation with or without mordants showed a clear, elegant yellow- to brown shade.

And the cashmere fabrics with dyed a nettle bio-preperation with and without metal mordants give a yellow, lightgreen to brown shade.

The use of mordants not only improves colour strength but also provides shade differences. To study reveals that dyeing parameters have significant effect on colour characteristics and quality of consumer quality properties of cashmere fabric. Some metal salts are used by mordants in the natural dyeing proceesing are increased 1-2 grade of colour fastness rating of dyed cashmere fabrics.

The cashmere fabrics dyed with rhubarb and nettle biopreperation solution with or without metal mordants have good to excellent UV rotection properties. In summary, cashmere fabrics can be successfully dyed with rhubarb and nettle bio-preperation solution with or without metal mordanting and can be used in the development of UV protective fabrics.

\section{REFERENCES}

[1] Khaidav, TS, B Alatanchimeg and TC Barlamova 1985. Medicinal plants of Mongolian medicine. State publishing, Ulaanbaatar, 8-40.

[2] Ligaa, V and ZH Gal. 2000. Resources of economical useful plants of Mongolia. Paper presented during the International Conference on Central Asian Ecosystem, Ulaanbaatar.

[3] Robertson S. M.; Dyes from Plants, New York: Van

[4] Bechbold, T.; Mussak, R. Handbook of Natural Colorants. John Wiley\&Sons Ltd, England. 2009.

[5] Allen R. L. M.; Colour Chemistry, London: Nelson, 1971, 6-7.

[6] Hill , D.J. Is There a Future for Natural Dyes?

[7] Bechtold, T.; Turcanu, A.; Ganglberger,E.; Geissler,S. Natural Dyes in Modern Textile Dyehouse-How to Combine Experiences of Two Centries to Meet the Demands of the Future? J.Cleaner Production. 2003, 11, 499-509.

[8] Kenneth, M.K. Color Characteristics of Traditional Vegetable Dyeing. Tex.Res.J.1973, 43, 404-407.

[9] Montazer, M.; Parvinzadeh,M. Deying of Wool with Marigold and its Properties. Fiber.Polym.2207, 8, 181-185.

[10] Popoola, A.V. Dyeability of Celllulose Fibers using Dyestuff from African Rosewood. J.Appl.Polym.Sci.2000 ,77, 746-751.

[11] Angelini, L.G.; Pistelli,L.; Belloni, P.; Bertoli, A.; Panconesi, S. Rubia tinctorum a Source of Natural Dyes. Ind. Crops Products, 1997, 6, 303-311. 
[12] Hwang, E.K.; Kim,M.S.; Lee, D.S.; Kim, K.B. Color Development of Natural Dyes with Some Mordants. J.Kor. Fiber Soc. 1998, 35, 490-497.

[13] Vankar P.S., Handbook on natural dyes for industrial applications, National institute of industrial research. Delhi, 2007.

[14] Shin, Y.S.; Choi, H. Characteristics and Dyeing Properties of Green Tea Colorants(Part.2). J.Kor.Soc.Cloth.Textil. 1999, 23, 385-390.

[15] Choi, K.R. Studies on the Natural Dye(11). J.Kor.Soc.Dyers Finishers. 1999, 11, 39-49.

[16] Cristea, D.; Vilarem, G. Improving Light Fastness of Natural Dyes on Cotton Yarn. Dyea Pigments. 2006, 70, 238-245.

[17] Lee, Y.H.; Hwang, E.K.; Kim, H.D. Dyeing and Fastness of Silk and Cotton Fabrics Dyed with Cherry Extract. J.Kor.Soc. Dyers Finishers. 2000, 12, 53-59.

[18] Lee, Y.H.; Kim, H.D. Dyeing properties and Color Fastness of Cotton and Silk Fabrics Dyed with cassia tora L. Extract. Fibers and Polymers. 2004, 5, 303-308.

[19] Anitha K and Prasad S N, Current Science, 2007, 92(12), 1681-1682.

[20] Adeel S, Ali S, Bhatti I A and Zsila F, Asian J Chem., 2009, 21(5), 3493-3499.

[21] Sachan K and Kapoor V P, Ind J Tradit Knowl., 2007, 6(2), 270-278.

[22] Siva R, Current Science, 2007, 92(7), 916-919.

[23] Vankar P S, Shankar R and Wijayapala S, Journal of Textile and Apparel, Technology and Management, 2009, 6(1), 1-11.

[24] Samanta A K and Agarwal P, Indian J Fib Text Res., 2009, 34, 384399.

[25] Mahangade R R, Varadarajan P V, Verma J K and Bosco H, Ind J Fib Tex Res., 2009, 34, 279-282.

[26] Wang L., Wang N., Jia S., Zhou Q. Research on Dyeing and Ultraviolet Protection of Silk Fabric Using Vegetable Dyes Extracted from Flos Sophorae. Textile Research Journal, Vol. 79(15), 2009, pp. 1402-1409.

[27] Gies P. H., Roy C. R., Holmes G.; Radiation Protection Dosimetry, Vol. 91(1-3), 2000, pp. 247-250

[28] 6. Feng X. X., Zhang L. L, Chen J. Y., Zhang J. C.; Journal of Cleaner Production, Vol. 15(4), 2007, pp. 366-372.

[29] Sarkar A. K.; BMC Dermatology, Vol. 4(15), 2004, pp. 1-8.

[30] Allen M. W., Bain, G. Measuring the UV protection factor of fabric. Retrieved March 25, 2008, from Varian Australia Pty Ltd.

[31] Tserendulam, S.; S.Delgermaa, S.; Nadmid, G.; Kh.Soyol-Undrakh, Tamara, M. Eco-friendly of cashmere dyeing with Rheum Undalitum L. and Urtica Cannabina L. 2017, $11^{\text {th }}$ international forum on strategic technology. IFOST 2017. Korea.

[32] Bhattacharya S. D., Shah A. K.; Coloration Technology, Vol. 116(1), 2000, pp. 10-12.

[33] 4. Vankar P.S., Handbook on natural dyes for industrial applications, National institute of industrial research. Delhi, 2007.

[34] Agarwal B. J., Patel B. H.; Studies on dyeing of wool with a natural dye using padding techniques. Man-Made Textiles in India. Vol. 45, 2002, pp. 237-241. 